\title{
Enhancing Landowner Adoption of the Natural Resource Conservation Service's Recommended Beef Cattle Grazing Management Practices
}

\author{
T. Olsovsky ${ }^{1}$, R. Strong ${ }^{2}$, A. Berthold ${ }^{3}$
}

\begin{abstract}
Water has a significant role in society, whether through human consumption or agricultural use. The Lavaca Watershed is an agricultural community affected by nonpoint source pollution, and water quality protection is of high concern. Beef cattle operations are linked to nonpoint source pollution which contaminates surrounding water sources. If proper grazing management practices are not used, wastes from the operation impair water quality in the area. Landowners should use proper stocking rates and implement best management practices to benefit land and water quality in addition to overall operation profit. Females reported a higher intention to adopt, indicating these respondents are more open to practice changes on their own operation. Results indicated a need for the Natural Resource Conservation Service (NRCS) and Texas Soil and Water Conservation Board to conduct further outreach to increase interaction with landowners. NRCS agencies could help increase the use of water conservation plans and inquiries by making this clear to current landowners participating in their program as well as potential clients by sending informational flyers or speaking at local organizational gatherings. The importance of adopting water management practices and barriers to adoption are ongoing global concerns.
\end{abstract}

\section{Keywords}

water, Texas, intention, awareness, diffusion

1. Taylor Olsovsky, Graduate Research Assistant, Texas A\&M University, 600 John Kimborough Blvd. Suite 263, College Station, TX 77843-2116, taylorolsovsky@gmail.com, iD https://orcid.org/0000-0003-0476-1440

2. Robert Strong, Associate Professor, Texas A\&M University, 600 John Kimborough Blvd. Suite 254, College Station, TX 77843-2116, r-strong@tamu.edu, iD https://orcid.org/0000-0001-5279-4808

3. Allen Berthold, Assistant Director, Texas Water Resources Institute, 578 John Kimbrough Blvd., College Station, TX 77843. taberthold@ag.tamu.edu, Dhttps://orcid.org/0000-0002-2604-1447 


\section{Introduction and Problem Statement}

The decline in water quality is a reoccurring concern, as water is one of our most significant resources. Agricultural practices alone use approximately $80 \%$ of the United States' water resources (National Institute of Food and Agriculture, n.d.). Many experts have stated increased communication and education on the impairment of water resources is essential in solving the water quality issue. Mulki et al. (2018) stressed the need for the public to take a role in actively conserving water resources through investing "in thorough communication strategies to engage and educate" (p. 117). The Lavaca Watershed has many bodies of water that are home to aquatic life and used recreationally (Texas Commission on Environmental Quality, 2019). Agricultural practices can negatively impact the water quality of the Lavaca Watershed.

Water quality protection is a high concern as an agricultural community affected by nonpoint source pollution. Devant et al. (2020) reported cattle performance relies on access to high quality water. Overstocking may cause the manure from cattle operations to deposit into the streams and rivers of the ecosystem through runoff water (Tarakalson et al., 2006). Redmon et al. (2012) indicated overgrazing depletes forage availability, which leads to decreased beef production efficiency and increases costs.

\section{Theoretical and Conceptual Framework}

The Theory of Planned Behavior (TPB) presents logic for why landowners' may or may not adopt new water conservation practices. Under critical review, Ajzen (1991) points out weak arguments, describing human behaviors as multifaceted. Therefore, Ajzen (1991) presents TPB as a model to predict and explain human behavior in a specific setting. This theory, as shown in Figure 1, involves predicting behavior by evaluating the relationship of behavioral intention to the three elements: attitude, perceived behavior control and subjective norms (Ajzen, 1991). In explaining the behavior, each element has a foundational belief, such as behavioral, control, or normative underlying the intention and action (Ajzen, 1991).

Rogers' (2003) Diffusion of Innovations provides understanding on the adoption process for an innovation, such as new products or practices. Diffusion is defined as "the process by which an innovation is communicated through certain channels over time among the members of a social system" (Rogers, 2003, p. 5). With the introduction of an innovation, there are uncertainties the influencer must alleviate prior to the persuasion stage (Rogers, 2003). The influencer clears those uncertainties through three types of knowledge including awareness-knowledge, how-toknowledge, and principles-knowledge (Rogers, 2003). This study focused on the awarenessknowledge. Awareness-knowledge informs the individual the innovation exits (Rogers, 2003). 


\section{Purpose}

The purpose of this study was to understand landowner adoption of the Natural Resource Conservation Service's recommended beef cattle grazing management practices. More specifically, the research objectives were to:

1. Describe Lavaca County landowner's knowledge of stocking rates;

2. Identify Lavaca County landowner's awareness of NRCS and TSSWCB; and

3. Explain Lavaca County landowner's intention to adopt grazing management practices.

\section{Methods}

A quantitative research design was used to analyze data collected through surveying the targeted population in Lavaca County, Texas. A mail survey was designed using the principles described by Dillman et al. (2014). The survey instrument measured the independent variables, demographics, knowledge levels, and awareness of the NRCS and TSSWCB in relation to the dependent variable, beef cattle producers' behavioral intention to adopt grazing management practices.

A simple random sample was acquired from the target population, landowners with beef cattle operations on their property. After contacting the Appraisal District's office, a contact list was acquired and further developed by eliminating duplicate landowners and land plots under ten acres, which does not qualify for agricultural tax exemptions. The final contact list comprised of 4,921 landowners, and 1200 landowners were surveyed. The final response rate was $39 \%$, with a total of 455 surveys received and 38 nondeliverable. One hundred ninety-four of the 455 were usable responses. Texas A\&M University faculty, Texas Water Conservation Board staff, and NRCS staff, assessed criterion validity of the instrument. All constructs were reliable; strategies to determining stocking rates $\alpha=0.81$; indicators of overstocking, $\alpha=0.83$, results of overstocking $\alpha=0.96$, advantages of using proper stocking rates $\alpha=0.97$; awareness of NRCS and TSSWCB $\alpha=0.85$. Intention to adopt was reliable, $\alpha=0.79$.

Dillman et al.'s (2014) Tailored Design Method was used for this study. Multiple contacts with a variety in appearance can help increase response rates (Dillman et al., 2014). Therefore, mailing the surveys occurred in four stages: prenotice postcard, 19 question survey package, reminder postcard, and finally the second 19 question survey package. To ensure landowners do not received duplicate surveys, a random identification number was assigned and printed on the survey package and envelopes. Data collection began early June, ended late July, and was extended due to COVID-19 effects on mailing. Early and late respondents' responses were examined Lindner et al. (2001) to assess nonresponse error. Significant differences did not exist between the two groups, and therefore, data can be generalized to the population. 


\section{Findings}

The first objective was to describe landowner's knowledge of beef cattle stocking rates.

Researchers utilized SPSS to analyze descriptive statistics for the knowledge items. Participants responded most favorably under advantages of properly stocking. With a mean score around five, this result indicated landowners agreed increased forage production, protection of soil and water resources, increased plant resiliency, higher body scores, decreased feeding period, decrease in supplemental feeding needs, and drought resilience were all advantages of using a proper stocking rate.

The grand mean of advantages of using a proper stocking rate was $M=5.10, S D=.80$. Overall, Results of Overstocking construct resulted in $M=5.05, S D=.87$. The construct, Indicators of Overstocking, had a grand mean, $M=4.65, S D=1.17$. Finally, landowners reported $M=4.11, S D$ $=1.31$ for Strategies to Determine Stocking Rate (see Table 1). 
Table 1

Descriptive Statistics for Knowledge

\begin{tabular}{|c|c|c|c|}
\hline Knowledge Items & $n$ & $M$ & $S D$ \\
\hline \multicolumn{4}{|l|}{ Advantages of Using a Proper Stocking Rate } \\
\hline Increased forage production & 179 & 5.21 & .72 \\
\hline Protection of soil and water resources & 180 & 5.19 & .82 \\
\hline Increased plant resiliency & 173 & 5.12 & .74 \\
\hline Higher Body Scores & 175 & 5.09 & .78 \\
\hline Decreased feeding period & 179 & 5.08 & .79 \\
\hline Decrease in supplemental feeding needs & 180 & 5.04 & .88 \\
\hline Drought resilience & 180 & 4.99 & .85 \\
\hline \multicolumn{4}{|l|}{ Results of Overstocking } \\
\hline Reduced land carrying capacity & 177 & 5.12 & .74 \\
\hline Increase in supplemental feeding needs & 180 & 5.12 & .84 \\
\hline Decrease in herd performance & 180 & 5.11 & .75 \\
\hline Decrease in forage production & 180 & 5.11 & .89 \\
\hline Susceptibility to drought & 179 & 5.09 & .96 \\
\hline Increased soil erosion and rainfall runoff & 178 & 5.08 & .96 \\
\hline Increased external parasites & 174 & 4.73 & .94 \\
\hline \multicolumn{4}{|l|}{ Indicators of Overstocking } \\
\hline Bare patches on the land & 181 & 4.86 & 1.08 \\
\hline Less desirable body scores & 171 & 4.85 & 1.04 \\
\hline Weed/brush encroachment & 179 & 4.63 & 1.23 \\
\hline Visible hooves from a distance & 173 & 4.49 & 1.26 \\
\hline Noticeable manure visible from a distance & 177 & 4.40 & 1.23 \\
\hline \multicolumn{4}{|l|}{ Strategies to Determine Stocking Rate } \\
\hline Based on forage availability & 175 & 5.00 & 1.06 \\
\hline $\begin{array}{l}\text { Based on calculated grazeable acres for my } \\
\text { pastures }\end{array}$ & 175 & 4.62 & 1.23 \\
\hline Based on preparation for change in season & 173 & 4.48 & 1.26 \\
\hline Based on current or anticipated market prices & 173 & 3.28 & 1.50 \\
\hline $\begin{array}{l}\text { Based on the county appraisal district's } \\
\text { recommendations }\end{array}$ & 162 & 3.18 & 1.48 \\
\hline
\end{tabular}

Note. Scale: 1 = Strongly Disagree, 2 = Disagree, $3=$ Somewhat Disagree, $4=$ Somewhat Agree, 5 = Agree, 6 = Strongly Agree.

In Table 2, descriptive statistics were given for age on knowledge of results of overstocking and indicators of overstocking. Participants 51-70 years of age indicated to agree with the items, less desirable body scores, weed/brush encroachment, and visible hooves from a distance while participants 71 and older varied and held lower means. 
The grand mean of the item, less desirable body scores, was $M=4.79, S D=1.09$. Weed/bush encroachment had an overall mean, $M=4.69, S D=1.20$. Lastly, landowners reported a grand mean, $M=4.51, S D=1.27$, for visible hooves from a distance.

\section{Table 2}

Descriptive Statistics of Age on Knowledge

\begin{tabular}{lccc}
\hline Knowledge Items & $n$ & $M$ & $S D$ \\
\hline Less desirable body scores & & & \\
$51-70$ & 80 & 5.01 & .83 \\
71 and over & 59 & 4.56 & 1.34 \\
Weed/brush encroachment & & & \\
$51-70$ & 83 & 4.76 & .98 \\
71 and over & 64 & 4.61 & 1.41 \\
Visible hooves from a distance & & & \\
$51-70$ & 81 & 4.58 & 1.17 \\
71 and over & 62 & 4.44 & 1.37 \\
\hline
\end{tabular}

Note. Scale: 1 = Strongly Disagree, 2 = Disagree, 3 = Somewhat Disagree, 4 = Somewhat Agree, 5 = Agree, 6 = Strongly Agree .

Provided in Table 3 are descriptive statistics for income on knowledge of advantages of properly stocking and results of overstocking. Landowners with $0-20 \%$ of their income came from the operation indicated higher agreement than landowners who receive $21-100 \%$ that increased forage production is an advantage of properly stocking and increased soil erosion and rainfall runoff is a result overstocking. The grand mean for increased forage production was $M=$ $5.11, S D=0.76$, and increased soil erosion and rainfall runoff, $M=4.86, S D=1.04$.

\section{Table 3}

Descriptive Statistics of Income on Knowledge

\begin{tabular}{lccc}
\hline Knowledge Items & $n$ & $M$ & $S D$ \\
\hline Increased forage production & & & \\
0-20\% of income & 136 & 5.28 & .66 \\
21-100\% of income & 31 & 4.94 & .85 \\
0-20\% of income & & & \\
21-100\% of income & 137 & 5.20 & .85 \\
\hline
\end{tabular}

Note. Scale: 1 = Strongly Disagree, 2 = Disagree, 3 = Somewhat Disagree, 4 = Somewhat Agree, 5 = Agree, 6 = Strongly Agree.

Landowner awareness of NRCS and TSSWCB is shown in Table 4. While the data showed many landowners were aware of the Lavaca Soil and Water Conservation District along with the local NRCS, many landowners indicated they were not aware that the technical and financial 
assistance received was confidential. Additionally, many indicated they were not aware that the agencies offer financial assistance for implementing practices. Overall, landowners indicated they were aware of the agencies purpose and free technical assistance available.

\section{Table 4}

Descriptive Statistics for Awareness of the Natural Resources Conservation Service \& Texas State Soil and Water Conservation Board

\begin{tabular}{lcccc}
\hline $\begin{array}{l}\text { Awareness of the Natural Resources Conservation } \\
\text { Services Items }\end{array}$ & $f$ & $\%$ Yes & $f$ & \% No \\
\hline $\begin{array}{l}\text { Did you know that any technical and financial } \\
\text { assistance that you receive is confidential? }\end{array}$ & 64 & 36 & 114 & 64 \\
$\begin{array}{l}\text { Did you know that the agencies mentioned above } \\
\text { offer financial assistance? }\end{array}$ & 88 & 49 & 92 & 51 \\
$\begin{array}{l}\text { Did you know that the agencies mentioned above } \\
\text { work with you to develop a water conservation } \\
\text { plan that will help attain your goals? }\end{array}$ & 104 & 59 & 73 & 41 \\
$\begin{array}{l}\text { Did you know that the agencies mentioned above } \\
\text { offer free technical assistance? }\end{array}$ & 118 & 62 & 66 & 34 \\
$\begin{array}{l}\text { Are you aware of the Natural Resources } \\
\text { Conservation Services? }\end{array}$ & 135 & 75 & 44 & 25 \\
$\begin{array}{l}\text { Did you know that the agencies mentioned above } \\
\text { work to protect and enhance your working lands } \\
\text { and natural resources? }\end{array}$ & 144 & 80 & 36 & 20 \\
$\begin{array}{l}\text { Are you aware of Lavaca Soil and Water } \\
\text { Conservation District? }\end{array}$ & 149 & 82 & 32 & 18 \\
\hline
\end{tabular}

Note. Scale: 1 = Yes, $2=$ No.

Descriptive statistics illustrated age on awareness of NRCS and TSSWCB. Both landowners, 5170 years old and 71 and older, reported unaware of NRCS and TSSWCB confidentiality. However, both age groups indicated awareness of NRCS and TSSWCB conservation plans (see Table 5). 


\section{Table 5}

Descriptive Statistics of Age on Awareness of Natural Resources Conservation Service \& Texas State Soil and Water Conservation Board

\begin{tabular}{lllll}
\hline Awareness Items & $f$ & $\%$ Yes & $f$ & $\%$ No \\
\hline $\begin{array}{l}\text { Did you know that any technical and financial } \\
\text { assistance that you receive is confidential? }\end{array}$ & & & & \\
$\quad 51-70$ & 23 & 28 & 58 & 72 \\
$\quad 71$ and over & 25 & 38 & 40 & 62 \\
Did you know that the agencies mentioned above & & & & \\
work with you to develop a water conservation plan & & & & \\
that will help attain your goals? & 43 & 52 & 39 & 48 \\
$\quad 51-70$ & 43 & 68 & 20 & 32 \\
\hline 71 and over
\end{tabular}

Note. Scale: $1=$ Yes, 2 = No

Education on awareness of NRCS and TSSWCB descriptive statistics were demonstrated in Table 6. Landowners with a graduate degree, bachelor's degree, and some college indicated lack of awareness while landowners with a high school diploma indicated awareness of NRCS and TSSWCB confidentiality.

\section{Table 6}

Descriptive Statistics of Education on Awareness of Natural Resources Conservation Service \& Texas State Soil and Water Conservation Board

\begin{tabular}{lcccc}
\hline Awareness Items & $f$ & $\%$ Yes & $f$ & $\%$ No \\
\hline $\begin{array}{l}\text { Did you know that any technical and financial } \\
\text { assistance that you receive is confidential? }\end{array}$ & & & & \\
$\quad$ Graduate Degree & 7 & 21 & 27 & 79 \\
Bachelor's Degree & 15 & 29 & 36 & 71 \\
$\quad$ Some college & 12 & 40 & 18 & 60 \\
$\quad$ High school graduate & 21 & 57 & 16 & 43 \\
\hline
\end{tabular}

Note. Scale: $1=$ Yes, $2=$ No

Descriptive statistics are given for gender on awareness of NRCS and TSSWCB. Males indicated less awareness than females of NRCS, TSSWCB, and confidentiality (see Table 7). 


\section{Table 7}

Descriptive Statistics of Gender on Awareness of Natural Resources Conservation Service \& Texas State Soil and Water Conservation Board

\begin{tabular}{lcccc}
\hline Awareness Items & $f$ & $\%$ Yes & $f$ & $\%$ No \\
\hline $\begin{array}{l}\text { Did you know that any technical and financial } \\
\text { assistance that you receive is confidential? }\end{array}$ & & & & \\
$\quad$ Male & 39 & 30 & 89 & 70 \\
$\quad$ Female & 21 & 49 & 22 & 51 \\
Are you aware of the Natural Resources Conservation & & & & \\
Services? & 94 & 73 & 34 & 27 \\
$\quad$ Male & 36 & 84 & 7 & 16 \\
$\quad$ Female & & & & \\
Are you aware of Lavaca Soil and Water Conservation & & & & \\
District? & 103 & 79 & 27 & 21 \\
$\quad$ Male & 39 & 91 & 4 & 8 \\
$\quad$ Female & & &
\end{tabular}

Note. Scale: $1=$ Yes, $2=$ No

In Table 8, income on awareness of NRCS and TSSWCB descriptive statistics were presented. Landowners who receive $0-20 \%$ of their household income from their beef cattle operation indicated less awareness of NRCS and TSSWCB items than landowners who receive $21-100 \%$ of their income from the operation. Landowners who receive $0-20 \%$ of their income from the operation indicated they were not aware of financial assistance offered by the NRCS while landowners who receive $21-100 \%$ from the operation were aware of the offer. 


\section{Table 8}

Descriptive Statistics of Agricultural Income on Awareness of Natural Resources Conservation Services \& Texas State Soil and Water Conservation Board

\begin{tabular}{|c|c|c|c|c|}
\hline Awareness Items & $f$ & $\%$ Yes & $f$ & $\%$ No \\
\hline \multicolumn{5}{|c|}{$\begin{array}{l}\text { Did you know that the agencies mentioned above offer } \\
\text { financial assistance? }\end{array}$} \\
\hline $0-20 \%$ & 60 & 43 & 78 & 57 \\
\hline $21-100 \%$ & 23 & 77 & 7 & 23 \\
\hline \multicolumn{5}{|c|}{$\begin{array}{l}\text { Did you know that the agencies mentioned above work } \\
\text { with you to develop a water conservation plan that will } \\
\text { help attain your goals? }\end{array}$} \\
\hline $0-20 \%$ & 74 & 55 & 61 & 45 \\
\hline $21-100 \%$ & 22 & 73 & 8 & 27 \\
\hline \multicolumn{5}{|c|}{$\begin{array}{l}\text { Did you know that the agencies mentioned above offer } \\
\text { free technical assistance? }\end{array}$} \\
\hline $0-20 \%$ & 84 & 61 & 54 & 39 \\
\hline $21-100 \%$ & 26 & 87 & 4 & 13 \\
\hline \multicolumn{5}{|c|}{$\begin{array}{l}\text { Are you aware of the Natural Resources Conservation } \\
\text { Services? }\end{array}$} \\
\hline $0-20 \%$ & 102 & 75 & 34 & 25 \\
\hline $21-100 \%$ & 26 & 84 & 5 & 16 \\
\hline \multicolumn{5}{|c|}{$\begin{array}{l}\text { Did you know that the agencies mentioned above work } \\
\text { to protect and enhance your working lands and natural } \\
\text { resources? }\end{array}$} \\
\hline $0-20 \%$ & 108 & 79 & 29 & 21 \\
\hline $21-100 \%$ & 27 & 87 & 4 & 13 \\
\hline \multicolumn{5}{|c|}{$\begin{array}{l}\text { Are you aware of Lavaca Soil and Water Conservation } \\
\text { District? }\end{array}$} \\
\hline $0-20 \%$ & 111 & 80 & 27 & 20 \\
\hline $21-100 \%$ & 28 & 90 & 3 & 10 \\
\hline
\end{tabular}

Note. Scale: $1=$ Yes, $2=$ No

The grand mean for landowner's intention to adopt grazing management practices was 3.44. Landowners already adopted the use of alternative water sources $(M=3.60, S D=1.00)$ and cross fencing $(M=3.60, S D=.92)$ on their operation. Landowners reported they either plan to adopt or already adopted the use of alternative feed/salt/mineral locations $(M=3.53, S D=.92)$. Finally, landowners indicated they plan to adopt alternative shade structures $(M=3.34, S D=$ 1.22), grazing plans $(M=3.30, S D=.96)$, and calculating grazeable acres for stocking rates $(M=$ $3.29, S D=1.01$ ) (see Table 9). 


\section{Table 9}

Descriptive Statistics for Intention to Adopt

\begin{tabular}{lccc}
\hline Intention to Adopt Items & $n$ & $M$ & $S D$ \\
\hline Alternative Water Sources & 179 & 3.60 & 1.00 \\
Cross Fencing & 178 & 3.60 & .92 \\
Alternative Feed/Salt/Mineral Locations & 178 & 3.53 & .92 \\
Alternative Shade Structures & 180 & 3.34 & 1.22 \\
Grazing Plan/Prescribed Grazing & 171 & 3.30 & .96 \\
Calculating Grazeable Acres for Stocking Rates & 175 & 3.29 & 1.01 \\
\hline
\end{tabular}

Note. Scale: $0=$ Not Applicable, $1=$ Will Not Adopt, $2=$ Undecided, $3=$ Plan to Adopt, $4=$ Already Adopted

Descriptive statistics were provided for gender on intention to adopt grazing management practices. Females indicated to have adopted calculating grazeable acres for stocking rates and grazing plans while males plan to adopt the practices. The grand mean among males and females for calculating grazeable acres for stocking rates was $M=3.39, S D=0.96$ and grazing plan, $M=3.37, S D=0.94$ (see Table 10).

\section{Table 10}

Descriptive Statistics of Gender on Intention to Adopt

\begin{tabular}{lccc}
\hline Grazing Management Practices & $n$ & $M$ & $S D$ \\
\hline Calculating Grazeable Acres for Stocking Rates & & & \\
$\quad$ Female & 41 & 3.63 & .89 \\
Male & 127 & 3.15 & 1.03 \\
Grazing plan/Prescribed Grazing. & & & \\
$\quad$ Female & 40 & 3.53 & .88 \\
Male & 124 & 3.20 & 1.00 \\
\hline
\end{tabular}

Note. Scale: $0=$ Not Applicable, $1=$ Will Not Adopt, $2=$ Undecided, $3=$ Plan to Adopt, $4=$ Already Adopted.

Provided in Table 11 were descriptive statistics for age on intention to adopt grazing management practices. Landowners $51-70$ years old adopted cross fencing while landowners 71 and older plan to adopt the practice. The grand mean for cross fencing among landowners 51-70 years old and 71 and over was $M=3.55, S D=0.97$. 


\section{Table 11}

Descriptive Statistics of Age on Intention to Adopt

\begin{tabular}{lllc}
\hline Grazing Management Practices & $n$ & $M$ & $S D$ \\
\hline Cross Fencing. & & & \\
$51-70$ & 85 & 3.61 & .87 \\
71 and over & 61 & 3.49 & 1.06 \\
\hline
\end{tabular}

Note. Scale: $0=$ Not Applicable, $1=$ Will Not Adopt, $2=$ Undecided, $3=$ Plan to Adopt, $4=$ Already Adopted.

Descriptive statistics were displayed for income on intention to adopt grazing management practices in Table 12. Landowners who receive $21-100 \%$ of their income from the operation adopted alternative feed/salt/mineral locations while landowners with 0-20\% of income from the operation plan to adopt the practice. The grand mean between income groups for alternative feed/salt/mineral locations was $M=3.64, S D=0.81$.

\section{Table 12}

Descriptive Statistics of Income on Intention to Adopt

\begin{tabular}{cccc}
\hline Grazing Management Practices & $n$ & $M$ & $S D$ \\
\hline Alternative Feed/Salt/Mineral Locations. & & & \\
21-100\% & 31 & 3.81 & .65 \\
$0-20 \%$ & 135 & 3.47 & .96 \\
\hline
\end{tabular}

Note. Scale: $0=$ Not Applicable, $1=$ Will Not Adopt, $2=$ Undecided, $3=$ Plan to Adopt, $4=$ Already Adopted.

\section{Conclusions, Discussion, and Recommendations}

Females indicated higher knowledge than males in determining stocking rate based on county appraisal district recommendations. These results suggest that females may be researching stocking rates more than males, looking to improve the operation. Landowners in the 0-20\% income group indicated higher knowledge than landowners earning between $21-100 \%$ of their income from the beef cattle operation. This result was a contradiction to the literature as landowners with more income coming from the operation would have more of a focus, leading to more knowledge (Peterson et al., 2015).

Landowners indicated awareness of the NRCS and TSSWCB yet lack of awareness in financial assistance and the confidentiality policy. Males and females both indicated awareness of the NRCS and TSSWCB. However, both males and females also showed they were unaware the technical and financial assistance provided by the NRCS is confidential. Males reported a higher mean than females, indicating males were more unaware than females. Similar to the knowledge and gender findings, this result also suggests that perhaps females are pursuing further research for the success of their operation. 
Landowners with some college, Bachelors, and Graduate degree were unaware of the technical and financial assistance they received was confidential. This result suggests there may be a misconception acting as a barrier to landowners engaging in assistance from the NRCS.

Rogers (2003) indicated knowledge is essential for a successful adoption rate of an innovation. In this case, females reported to have knowledge and intention to adopt, confirming Rogers' (2003) theory. Also, Ajzen (1991) predicted, a favorable attitude is an element leading to a higher likelihood of intention to adopt. Females appear to have a more favorable attitude with an indication they are more open to change on their operation. Consistently, assistance from the NRCS being confidential was significant in relation to adoption of practices. Landowners who were unaware of NRCS confidentiality had a lower intention to adopt. This confirms Rogers' (2003) emphasis on trust when adopting a new practice. Landowners indicate to be unaware of NRCS confidentiality, and privacy is a valued aspect of working with a government agency.

Practitioners such as Extension and NRCS agencies should take a step towards making landowners more aware of the resources available. Given the females' results, females might reach out to these agencies and develop positive working relationships that will increase the likelihood others reach out for help.

Also, data indicated a common theme in landowners not being aware that working with the NRCS is confidential. NRCS agencies could help increase the use of water conservation plans and inquiries by making this clear to current landowners participating in their program as well as potential clients by sending informational flyers or speaking at community civic or development organizational gatherings. Sharing this conservation responsibility with the public can increase awareness of the potential impact and create the change society needs to live healthy lives.

There are multiple inquiries for researchers to investigate moving forward from this finding. Further research is necessary to determine the cause of the difference in females over males in their knowledge and intention to adopt. Additionally, researchers can further explore interaction or lack thereof between the public and the NRCS. Research could confirm the extent confidentiality and privacy have a role in whether landowners engage with the NRCS. Future researchers should examine the role of NRCS' electronic information dissemination efforts on stakeholders learning, adoption, and program impact.

\section{Acknowledgements}

Funding for this project was provided by the Texas State Soil and Water Conservation Board through a state nonpoint source grant. 


\section{References}

Ajzen, I. (1991). The theory of planned behavior. Organizational Behavior and Human Processes, 50(2), 179-211. https://doi.org/10.1016/0749-5978(91)90020-T

Devant, M., Verdu, M., Medinya, C., Riera, J., \& Marti, S. (2020). PSXI-11 Drinking device can reduce apparent water consumption and improve device cleanliness without impairing calf performance. Journal of Animal Science, 98(4), 389. https://doi.org/10.1093/jas/skaa278.685

Dillman, D. A., Smyth, J. D., \& Christian, L. M. (2014). Mail and internet surveys: The Tailored Design Method (4th ed.). John Wiley \& Sons.

Lindner, J. R., Murphy, T., \& Briers, G. E. (2001). Handling nonresponse error in social science research. Journal of Agricultural Education, 42(4), 43-53. https://doi.org/10.5032/jae.2001.04043

Mulki, S., Rubinstein, C., \& Saletta, J. (2018) Texas' water quality challenge and the need for better communication in an era of increasing water quality contamination events. Texas Water Journal, 9(1), 108-119. https://twj.media/wpcontent/uploads/2018/10/Mulki.opt .pdf

National Institute of Food and Agriculture. (2020, December 15). Water. U. S. Department of Agriculture. https://nifa.usda.gov/topic/water

Redmon, L., Wagner, K., \& Peterson J. (2012). Lonestar healthy streams: Beef cattle manual. (Extension Publication No. B-6245) Texas A\&M AgriLife Extension Service. http://lshs.tamu.edu/media/340444/beef_cattle.pdf

Rogers, E. M. (2003). Diffusion of innovations (5th ed.). Free Press.

Tarakalson, D. D., Payero, J. O., Ensley, S. M., \& Shapiro, C. A. (2006). Nitrate accumulation and movement under deficit irrigation in soil receiving cattle manure and commercial fertilizer. Agricultural Water Management, 85(1-2), 201-210. https://doi.org/10.1016/j.agwat.2006.04.005

Texas Commission on Environmental Quality. (2020, October 29). Lavaca River above tidal and rocky creek: A community project to protect recreational uses. https://www.tceq.texas.gov/waterquality/tmdl/nav/lavaca-rocky/108-lavaca-rocky$\underline{\text { bacteria }}$

(C) 2021 by authors. This article is an open access article distributed under the terms and conditions of the Creative Commons Attribution license (http://creativecommons.org/licenses/by/4.0/). 